\title{
THE WEALTH EFFECTS OF TARGETED SHARE REPURCHASES
}

\author{
Michael BRADLEY* \\ University of Michigan, Ann Arbor, MI 48109, USA \\ L. Macdonald WAKEMAN* \\ University of California, Los Angeles, CA 90024, USA
}

Received December 1981, final version received September 1982

\begin{abstract}
This paper examines the wealth impact of share repurchases that restrict participation to a particular sub-set of a firm's stockholders. Repurchases at a premium from insiders and small shareholders increase the wealth of non-participating stockholders and are therefore consistent with the shareholders' interest hypothesis. However, privately negotiated repurchases of single blocks from stockholders unaffiliated with the firm reduce the wealth of non-participating stockholders. In contrast to the evidence for general repurchases, no positive wealth effect offsets the significant repurchase premium paid to the selling stockholder. Indeed, the wealth loss to non-participating stockholders is significantly greater than the premium paid. This evidence is inconsistent with the shareholders' interest hypothesis and supports the hypothesis that managers in their self-interest use single block repurchases to eliminate threats to their control over the firm's resources.
\end{abstract}

\section{Introduction and summary}

Since firms pay a premium over the market price when they repurchase their common stock through a general tender offer, the price of the remaining shares should, ceteris paribus, fall. However, Masulis (1980b), Dann (1981), Vermaelen (1981) and Rosenfeld (1982) find that the price of the remaining shares after the termination of an intrafirm tender offer is significantly above the price prior to its announcement. Dann (1980) and Vermaelen further show that an open market repurchase also has a positive impact on the price of the remaining shares. This evidence indicates that common share repurchases through tender offers and open market purchases

\footnotetext{
*We are grateful to Michael D. Ryngaert for both research and computational assistance. This paper has benefited from the comments of George Benston, Andrew Christie, James Ferguson, Paul Griffin, Ronald Masulis, Ross Watts, Jerry Zimmerman, the referee, Gene Fama, and especially Michael Jensen. The cross-sectional tests of the paper were developed in consultation with Gregg Jarrell. We are also indebted to the participants in seminars at the Bureau of Economics of the Federal Trade Commission. INSEAD, The London Business School, University of California-Davis, University of Rochester, University of Toronto and Washington University-St. Louis. Financial support for this research was provided to M. Bradley by the Graduate School of Business, University of Michigan, and to L.M. Wakeman by the Managerial Economics Research Center, University of Rochester.
} 
are in general consistent with the hypothesis that corporate managers act in their shareholders' interest.

In this paper, we examine stock repurchases which restrict participation to a particular sub-set of a firm's stockholders. These targeted groups include insiders, other corporations and shareholders owning less than 100 shares. We find that repurchases from insiders and small shareholders increase the wealth of non-participating stockholders and are therefore consistent with the shareholders' interest hypothesis. However, privately negotiated repurchases of single blocks from individuals unaffiliated with the firm and other corporations reduce the wealth of non-participating stockholders.

In order to examine the motivation behind these single block repurchases, we isolate those cases in which the repurchase signals the termination of a take-over attempt. For the sellers in this 'merger' subsample, the unusually large premium received for the block fully offsets the market's negative response to the termination of the take-over bid. But for repurchasing firms, the payment of this premium, which averages $19 \%$, compounds the negative effect of the lost take-over opportunity, and the non-participating shareholders suffer a significant wealth loss. We believe that this evidence is inconsistent with the shareholders' interest hypothesis. The results suggest that the managers of these repurchasing firms, acting in their own interest, are able to 'bribe' the sellers into abandoning profitable take-overs.

\section{Sample design}

An initial sample of targeted repurchases for the period 1974-1980 was collected from The Wall Street Journal Index. For 1978-1980, the 'Reacquired Shares' entry in the 'General News' section of the annual index was the primary source. Data for earlier years were obtained by an exhaustive reading of the annual 'Corporate News' section. The dates were then checked with the relevant issues of The Wall Street Journal. The final sample also met the following criteria:

(1) No other information concerning the company was reported in The Wall Street Journal in the three-day period surrounding the targeted share repurchase date.

(2) There were no problems in dating the announcement and the repurchase was not part of a previously announced plan.

(3) The bid to repurchase the block was successful.

(4) Daily rates of return on the common stock are available for the 300 days before the announcement on the CRSP file of companies quoted on the New York and American exchanges. 
The final sample of small share repurchases consists of 15 repurchase offers made to shareholders owning less than 100 shares in the period 1975-1979. The range of the premium over market price offered is from $0 \%$ to $45 \%$, with a mean of $10 \%$ and a median of $9 \%$.

The final sample of single block repurchases consists of 86 repurchases from insiders, individuals unaffiliated with the firm and other corporations in the period 1974-1980. Twenty-four of these blocks were repurchased at discounts from the market price. However, these discounts are calculated relative to the closing price two days prior to the offer announcement and, for all but one of these repurchases, the offer price was greater than the lowest daily market price reported during the previous month. The summary statistics presented in table 1 for this sample show that the blocks repurchased from corporations and individuals are slightly larger and receive higher premia than those repurchased from insiders, estates and foundations.

\section{Single block repurchases}

\subsection{Alternative hypotheses}

The curious aspect of single block repurchases is that they are generally made at a premium above market, which implies a wealth-loss for the nonparticipating shareholders. This immediately raises the interesting question: Do managers act in their shareholders' interest when repurchasing single blocks at a premium?

There are numerous ways in which a single block repurchase - even at a premium - could increase the wealth of the non-participating stockholders. The repurchase could signal favorable inside information to the market, or cause a value-increasing change in the firm's capital structure. For example, one company in our sample stated that the single block repurchase 'demonstrates the confidence of this management and our board of directors in (the firm's) future', and several companies noted that the block repurchase was being financed by loans. Some companies repurchased the block for 'general corporate purposes', noting that this new treasury stock would be used for employee benefit plans, stock dividends or future acquisitions. Several companies explained that they repurchased a block to preclude the selling firm from distributing the block to its stockholders, thereby increasing the company's servicing costs. These are all valid reasons for a firm to repurchase its own shares, and purchasing a single block - as opposed to a general tender offer - may be the more efficient way of accomplishing one of these objectives. Brokerage fees are avoided and information dissemination and collection costs are vastly reduced by reacquiring shares through one large, single block transaction. 


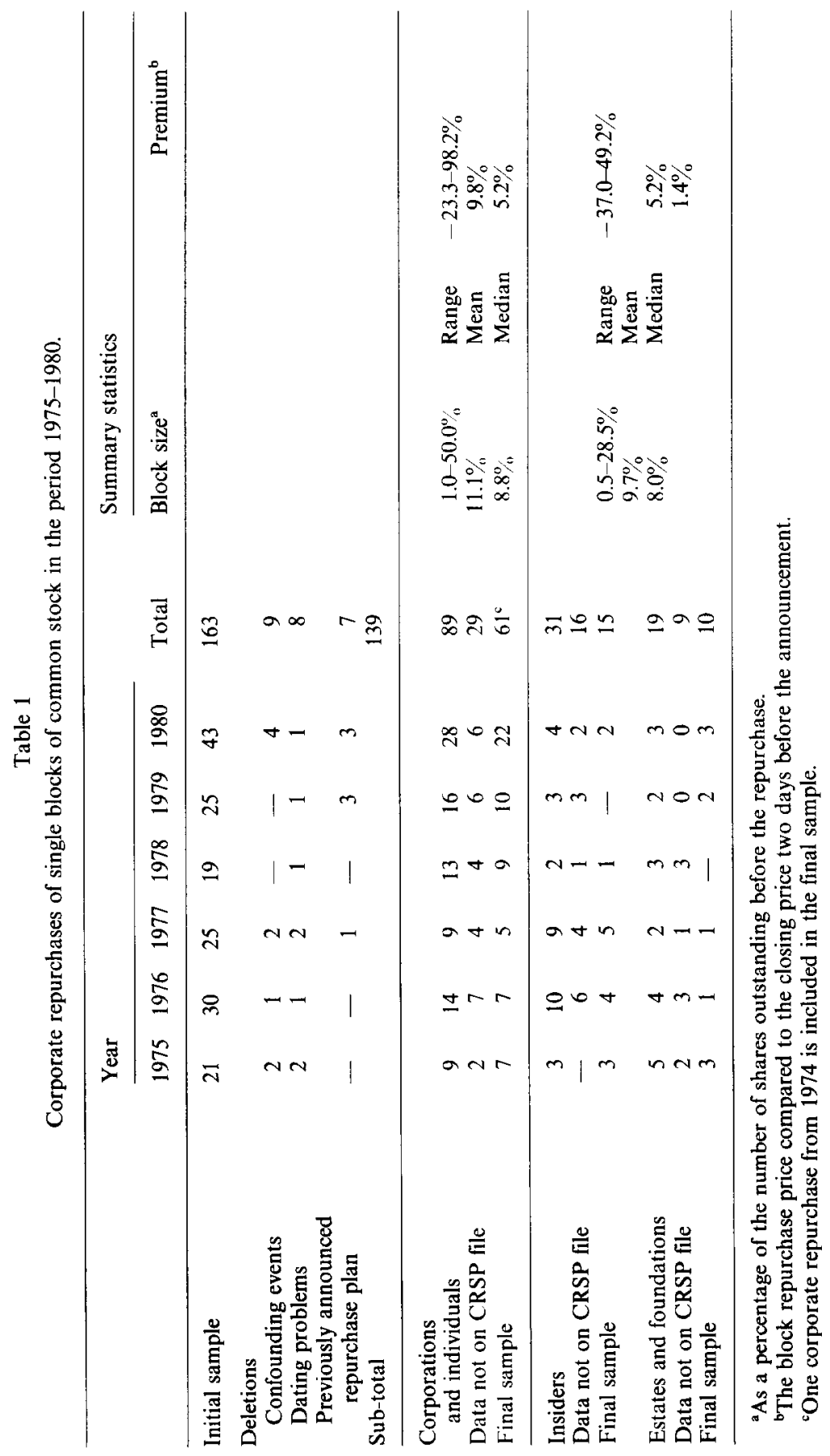


Other reasons given for block repurchases involve the costs of having another company control a significant fraction of a firm's voting stock. Many repurchases in our sample ended litigation concerning the purchase of the initial block, tender offers and proxy fights and were justified as actions which ended 'disruptive efforts to elect representatives to the board and influence management' or resolved 'disputes that could have seriously affected the conduct of business.' These costs of outside disruptions may be quite substantial. Uncertainty about the future nature (existence) of the firm could increase the costs of contracting with customers, suppliers and employees. Moreover, having representatives on the board of directors whose primary interest is the welfare of the stockholders of another firm could pose serious problems in formulating optimal business strategies. As Dann and DeAngelo (1982) point out, eliminating these outside disruptions through a block repurchase could very well increase the value of the repurchasing firm.

All of the above explanations for single block repurchases are consistent with the hypothesis that managers act in their shareholders' interest. Any one could explain why a block repurchase could lead to an increase in the value of a repurchasing firm.

There is, however, an alternative hypothesis to explain single block repurchases. Alchian and Demsetz (1972) and Jensen and Meckling (1976) view the firm as a set of contracts among managers, workers, bondholders and stockholders. Within this 'nexus of contracts', one of the more valuable benefits for a manager is his effective control of the firm, which allows him to pursue his own interests subject to the arrangements made by the principals to monitor his performance as their agent. In this context, the positive costs of writing and enforcing contracts preclude the shareholders from completely eliminating aberrant managerial activities. But concentrated shareholdings do provide a tighter constraint on the resulting managerial inefficiency than dispersed shareholdings since the marginal benefit of monitoring the manager is higher and the cost of removing the manager is lower for large shareholders. This theory of agency implies that managers repurchase a single block of common stock to reduce the probability of losing control of the firm's resources. Our sample provides several instances in which nonparticipating stockholders accused the managers of protecting their own interests. For example, one shareholder lawsuit specifically charged that the 'firm's recent purchase of 293,800 of its shares from Crane Co. was made for no other reason than to keep Morrison-Knudsen's management and directors in office'.

The divergence between these two hypotheses is most noticeable for blocks repurchased at a premium over market. The wealth transfer implied by this premium should, ceteris paribus, cause the price of the remaining shares to fall. If the shareholders' interest hypothesis is correct, managers will only accept a project if it has positive net present value for their shareholders. 
This implies that the wealth transfer will be offset by a concomitant wealthenhancing effect such that the price of the remaining shares rises. In contrast, the managers' interest hypothesis posits that there will be no such offset. Furthermore, if the block repurchase reduces the threat of a take-over and thereby allows managers to deviate further from value-maximizing behavior, the remaining shareholders will suffer an additional loss.

In the next section, we test these competing hypotheses and also analyze the returns to the shares of the selling companies.

\subsection{Time series analysis}

\subsubsection{Methodology}

In order to test the competing hypotheses of the previous subsection, we use the simple 'market' model

$$
\tilde{R}_{j t}=\alpha_{j}+\beta_{j} \tilde{R}_{m t}+\tilde{\varepsilon_{j t}}
$$

where $\tilde{R}_{j t}$ is the simple rate of return for security $j$ on day $t$ and $\tilde{R}_{m t}$ is the simple rate of return for the CRSP equally weighted market index on day $t$. We use it to estimate the alpha and beta of the common stock of each of the companies in the sample for the 240 trading day period ending 61 trading days before the announccment date: the day on which The Wall Street Journal first publishes the news of the repurchase. ${ }^{1}$ These estimates are then used to calculate the abnormal return of each security for the following 121 trading days according to the equation

$$
A R_{j \mathrm{t}}=\tilde{R}_{j t}-\left(\hat{\alpha}_{j}+\hat{\beta}_{j} \tilde{R}_{m t}\right)
$$

where $A R_{j t}$ is the abnormal return to security $j$ on day $t$, where $t$ is equal to zero on the announcement date, is negative for days before the announcement and is positive for days after the announcement.

In analyzing the time series of abnormal returns, we report statistics based on two time periods: three-day returns from $t=-1$ through $t=1$ and twentyday returns from $t=-1$ through $t=18$. The first time period is intended to capture the market's immediate reaction to the announcement of a repurchase; the second is intended to capture the market's assessment of the implications of this repurchase on share valuations. Because of our selection criteria, there is reason to believe that the full implication of the repurchase

\footnotetext{
${ }^{1}$ See Fama (1976) for details of this methodology. The Dimson (1979) technique, using $\bar{R}_{m, t-1}$, $\tilde{R}_{m t}$ and $\tilde{R}_{m, t+1}$ as the independent variables, was also employed. The results are qualitatively similar to those reported here, with the $t$-statistics on the abnormal returns being more significant because of lower standard errors.
} 
will not be reflected in market values within the three days surrounding the offer.

In order to be included in our sample, a repurchase agreement must not only have been announced but it must have been executed as well. For any repurchase announcement, there is some uncertainty as to whether or not the repurchase will be completed. Before it can be executed, the agreement must be approved by the firm's board of directors and its stockholders, at a special meeting. Also, stockholder suits to enjoin the repurchase must be adjudicated before the agreement can be carried out. As the uncertainty about these issues is resolved in the period following the initial announcement, the probability of repurchase for the 'successfully completed' sample (i.e., our sample) must go to one, causing a drift in the cumulative abnormal return to the portfolio.

\subsubsection{The effect of single block repurchases on the wealth of participating and non-participating stockholders}

The average abnormal return on day $t$ and the cumulative average abnormal return to day $t$ from 60 days before the announcement of the offer for the portfolios of repurchasing and selling firms are presented in table 2 . The time-series of the cumulative abnormal returns for these portfolios are plotted in fig. 1. These data indicate that the announcement of a single block repurchase increases the wealth of the stockholders of the selling firm. The cumulative abnormal return $(C A R)$ to the portfolio of selling firms calculated over the three-day interval from one day before the announcement appeared in The Wall Street Journal through one day aftcr, $C A R_{-1,1}$, is $1.40 \%$ with a $t$-statistic of $2.24 .^{2}$ In addition, 16 of the individual $C A R_{-1,1}$ statistics for the 28 firms in the sample are positive.

The evidence in table 2 and fig. 1 also indicates that the repurchase decreases the wealth of the repurchasing firm's remaining shareholders. For the portfolio of repurchasing firms, the $C A R_{-1,1}$ statistic is $-2.85 \%$ with a $t$-statistic of -5.82 , and 43 of the individual $C A R_{-1,1}$ statistics for the 61 firms in the sample are negative. The average 20 -day cumulative abnormal return, $C A R_{-1,18}$, for the portfolio of repurchasing firms is $-3.03 \%$ with a $t$-statistic of -1.97 , and 39 of the $61 C A R_{-1.18}$ statistics for the firms in the sample are negative.

While the above results indicate that a share repurchase is a wealthreducing event for non-participating shareholders, they do not imply malfeasance on the part of the repurchasing firm's managers. Many of the

\footnotetext{
${ }^{2}$ The three-day $t$-statistic is calculated using the standard deviation of the 80 three-day abnormal returns to the portfolio over the 240 -day period used to estimate the market model parameters. This methodology is used throughout this paper to calculate the standard errors of the reported CAR statistics. See Masulis (1980a) and Dann (1981) for a detailed description and justification of this estinator of the standard error.
} 


\section{Table 2}

Daily abnormal returns to the common stock of 61 companies repurchasing single blocks and 28 companies $^{\mathrm{a}}$ selling single blocks in the period 1974-1980.

\begin{tabular}{|c|c|c|c|c|}
\hline \multirow[b]{2}{*}{$\begin{array}{l}\text { Days relative to } \\
\text { the announcement } \\
\text { date }\end{array}$} & \multicolumn{2}{|c|}{ Repurchasing firms } & \multicolumn{2}{|l|}{ Selling firms } \\
\hline & $\begin{array}{l}\text { Daily } \\
\text { average } \\
\text { abnormal } \\
\text { return }\end{array}$ & $\begin{array}{l}\text { Cumulative } \\
\text { average } \\
\text { abnormal } \\
\text { return }\end{array}$ & $\begin{array}{l}\text { Daily } \\
\text { average } \\
\text { abnormal } \\
\text { return }\end{array}$ & $\begin{array}{l}\text { Cumulative } \\
\text { average } \\
\text { abnormal } \\
\text { return }\end{array}$ \\
\hline-60 & N.A. ${ }^{b}$ & 0.0068 & N.A. ${ }^{b}$ & 0.0076 \\
\hline-50 & & 0.0065 & & 0.0210 \\
\hline-40 & & 0.0173 & & 0.0153 \\
\hline-30 & & 0.0080 & & 0.0080 \\
\hline-20 & & 0.0071 & & 0.0064 \\
\hline-10 & & 0.0044 & & -0.0009 \\
\hline-9 & -0.0060 & -0.0017 & 0.0004 & -0.0005 \\
\hline-8 & -0.0029 & -0.0045 & -0.0032 & -0.0037 \\
\hline-7 & -0.0010 & -0.0055 & 0.0024 & -0.0008 \\
\hline-6 & 0.0110 & 0.0056 & 0.0064 & 0.0056 \\
\hline-5 & 0.0030 & 0.0086 & 0.0020 & 0.0076 \\
\hline-4 & -0.0055 & 0.0031 & 0.0015 & 0.0092 \\
\hline-3 & 0.0023 & 0.0054 & -0.0056 & 0.0036 \\
\hline-2 & 0.0008 & 0.0062 & 0.0030 & 0.0065 \\
\hline-1 & -0.0090 & -0.0028 & 0.0100 & 0.0166 \\
\hline 0 & -0.0115 & -0.0142 & 0.0028 & 0.0193 \\
\hline 1 & -0.0080 & -0.0223 & 0.0011 & 0.0205 \\
\hline 2 & 0.0028 & -0.0195 & 0.0059 & 0.0264 \\
\hline 3 & -0.0001 & -0.0196 & 0.0043 & 0.0306 \\
\hline 4 & 0.0008 & -0.0188 & 0.0003 & 0.0310 \\
\hline 5 & 0.0023 & -0.0165 & 0.0022 & 0.0332 \\
\hline 6 & -0.0014 & -0.0179 & -0.0011 & 0.0321 \\
\hline 7 & -0.0001 & -0.0180 & 0.0019 & 0.0340 \\
\hline 8 & 0.0038 & -0.0142 & 0.0028 & 0.0368 \\
\hline 9 & -0.0078 & -0.0220 & 0.0010 & 0.0379 \\
\hline 10 & 0.0023 & -0.0197 & 0.0037 & 0.0415 \\
\hline 20 & & -0.0264 & & 0.0142 \\
\hline 30 & & -0.0322 & & 0.0432 \\
\hline 40 & & -0.0315 & & 0.0500 \\
\hline 50 & & -0.0178 & & 0.0333 \\
\hline 60 & & -0.0224 & & 0.0419 \\
\hline Daily standard error & \multicolumn{2}{|c|}{0.0035} & \multicolumn{2}{|l|}{0.0039} \\
\hline 3-day standard error & \multicolumn{2}{|c|}{0.0049} & \multicolumn{2}{|l|}{0.0062} \\
\hline 20-day standard error & \multicolumn{2}{|c|}{0.0154} & \multicolumn{2}{|l|}{0.0139} \\
\hline
\end{tabular}

33 of the 61 sellers were individuals or corporations for which returns data are not readily available.

${ }^{b}$ Not applicable. 

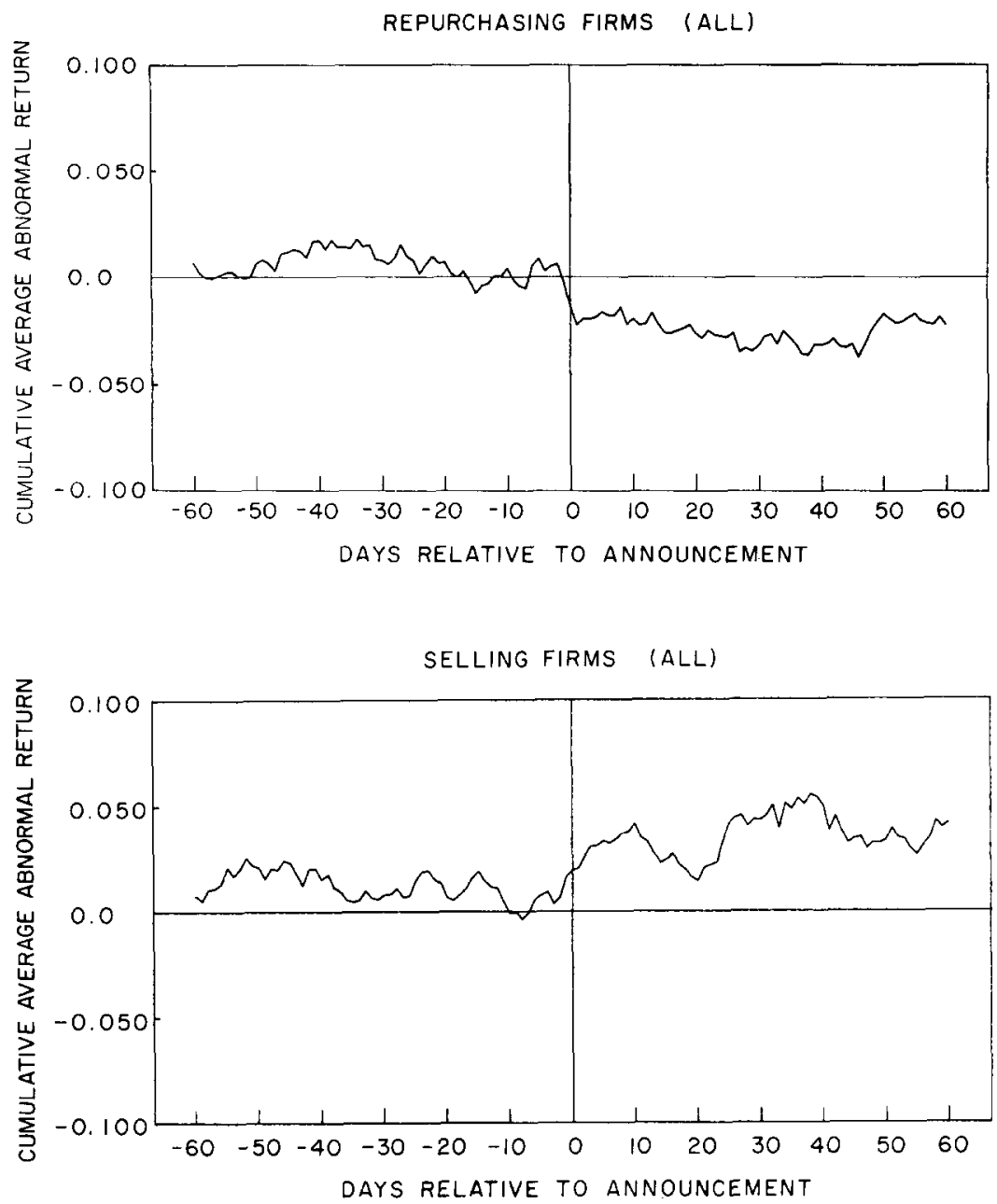

Fig. 1. Plots of cumulative average abnormal returns for 61 companies repurchasing single blocks and 28 companies selling single blocks in the period 1974-1980.

repurchases in our sample mark the termination of an attempt by the selling firm to acquire control of the repurchasing firm. The fall in the price of the shares of the repurchasing firm may simply reflect the discovery by the selling firm that the repurchasing firm does not, after all, possess the specialized resource that is necessary for a profitable acquisition. We examine the effect of merger terminations on our results in the next section. 


\subsubsection{Merger terminations}

Without notable exception, the empirical literature on corporate acquisitions finds that the shareholders of target firms gain when a merger or tender offer is announced and suffer a wealth-loss when these take-over bids are withdrawn. However, there is no consensus regarding the returns realized by stockholders of acquiring firms. Dodd (1980) reports a slight gain to these shareholders when a merger is terminated, but the evidence on merger announcements is mixed. Dodd and Ruback (1977) and Bradley (1980) report a positive effect, Mandelker (1974) finds no abnormal returns, and Langetieg (1978), Dodd (1980) and Malatesta (1981) detail a slight wealth loss to the acquiring stockholders. In sum, if a repurchase signals the termination of a previously announced take-over bid, we can predict that the value of the repurchasing firm will fall, but we cannot predict the effect on the value of the sclling firm.

In an attempt to isolate the influence of merger terminations on our results, we divide the sample into two sub-samples. In the first sub-sample we group all offers which we suspect mark the termination of a take-over attempt by the seller; all other repurchases are grouped into the second, 'non-merger', sub-set.

The merger termination sample consists of 21 repurchases. Thirteen of these are from selling firms who had initially bought the block within the previous 12 months and had announced a desire to seek control of the repurchasing firm. All of these sellers stated that the repurchase marked the end of their take-over plans. An additional 4 repurchases are from recognized conglomerates who had purchased the block within the previous 12 months and showed no further interest in the repurchasing firm. The other 4 are included because the repurchase was accompanied by a 'standstill' agreement, which is a contract precluding the selling firm from buying the repurchasing firm's shares for some stipulated period. ${ }^{3}$

The 'non-merger' sample consists of 40 repurchases. Thirty-four were from individuals or firms who initially bought the firm's shares more than 12 months before the repurchase agreement. Thirty of these 34 buyers never announced an intent to acquire the repurchasing firm; 4 had done so but, previous to the repurchase agreement, had announced that they were abandoning their take-over attempt. In the remaining 6 cases, the block had been initially bought within 12 months of the repurchase, but the

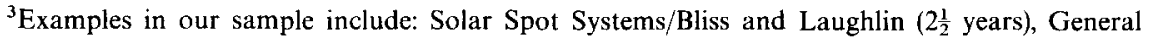
Host/Host International (5 years), Clabir/General Host (5 years), Spencer/Initio Financial Inc. (5 years), Chemed/Quaker ( 7 years), Reece/Walco ( 7 years), Dynamics/Unitrode (10 years), General Host/Ponderosa (10 years), and Televest Inc./Berkely Bio. Medical Inc. (extended period). The agreement between Kerkorian and Columbia Pictures prevents him from repurchasing any shares or joining any proxy contest for 10 years, and, when selling his $16.5 \%$ stake in Western Airlines, he agreed that he and his associates would not stand for re-election to the board of directors.
} 
accompanying take-over attempt had been thwarted by an unsuccessful tender offer or by a court ruling.

Table 3

Daily abnormal returns to the common stock of 40 companies repurchasing single blocks unaccompanied by a merger termination and 21 companies repurchasing single blocks accompanied by a merger termination in the period 1974-1980.

\begin{tabular}{|c|c|c|c|c|}
\hline \multirow[b]{2}{*}{$\begin{array}{l}\text { Days relative to } \\
\text { the announcement } \\
\text { date }\end{array}$} & \multicolumn{2}{|c|}{ No merger termination } & \multicolumn{2}{|c|}{ Merger termination } \\
\hline & $\begin{array}{l}\text { Daily } \\
\text { average } \\
\text { abnormal } \\
\text { return }\end{array}$ & $\begin{array}{l}\text { Cumulative } \\
\text { average } \\
\text { abnormal } \\
\text { return }\end{array}$ & $\begin{array}{l}\text { Daily } \\
\text { average } \\
\text { abnormal } \\
\text { return }\end{array}$ & $\begin{array}{l}\text { Cumulative } \\
\text { average } \\
\text { abnormal } \\
\text { return }\end{array}$ \\
\hline-60 & N.A. ${ }^{a}$ & 0.0100 & N.A. ${ }^{a}$ & 0.0004 \\
\hline-50 & & 0.0152 & & -0.0101 \\
\hline-40 & & 0.0201 & & 0.0121 \\
\hline-30 & & 0.0146 & & -0.0045 \\
\hline-20 & & 0.0131 & & -0.0044 \\
\hline-10 & & -0.0038 & & 0.0196 \\
\hline-9 & -0.0108 & -0.0146 & 0.0029 & 0.0225 \\
\hline-8 & -0.0026 & -0.0171 & -0.0034 & 0.0191 \\
\hline-7 & 0.0034 & -0.0138 & -0.0091 & 0.0010 \\
\hline-6 & 0.0151 & 0.0013 & 0.0033 & 0.0133 \\
\hline-5 & 0.0021 & 0.0034 & 0.0049 & 0.0181 \\
\hline-4 & -0.0041 & -0.0008 & -0.0081 & 0.0100 \\
\hline-3 & -0.0008 & -0.0016 & 0.0083 & 0.0183 \\
\hline-2 & 0.0017 & 0.0001 & -0.0008 & 0.0176 \\
\hline-1 & 0.0020 & 0.0021 & -0.0289 & -0.0113 \\
\hline 0 & -0.0076 & -0.0055 & -0.0187 & -0.0300 \\
\hline 1 & -0.0083 & -0.0138 & -0.0075 & -0.0375 \\
\hline 2 & 0.0023 & -0.0115 & 0.0038 & -0.0337 \\
\hline 3 & 0.0025 & -0.0090 & -0.0050 & -0.0387 \\
\hline 4 & 0.0021 & -0.0069 & -0.0017 & -0.0404 \\
\hline 5 & 0.0039 & -0.0030 & -0.0009 & -0.0413 \\
\hline 6 & 0.0011 & -0.0014 & -0.0063 & -0.0475 \\
\hline 7 & 0.0018 & -0.0000 & -0.0038 & -0.0513 \\
\hline 8 & 0.0050 & 0.0049 & 0.0016 & 0.0497 \\
\hline 9 & -0.0105 & -0.0055 & -0.0027 & -0.0524 \\
\hline 10 & 0.0061 & 0.0006 & -0.0049 & -0.0572 \\
\hline 20 & & 0.0089 & & -0.0931 \\
\hline 30 & & 0.0066 & & -0.1073 \\
\hline 40 & & 0.0099 & & -0.1124 \\
\hline 50 & & 0.0207 & & -0.0900 \\
\hline 60 & & 0.0205 & & -0.1063 \\
\hline Daily standard error & \multicolumn{2}{|c|}{0.0048} & \multicolumn{2}{|c|}{0.0050} \\
\hline 3-day standard error & \multicolumn{2}{|c|}{0.0071} & \multicolumn{2}{|c|}{0.0077} \\
\hline 20-day standard error & \multicolumn{2}{|c|}{0.0151} & \multicolumn{2}{|c|}{0.0281} \\
\hline
\end{tabular}

aNot applicable. 


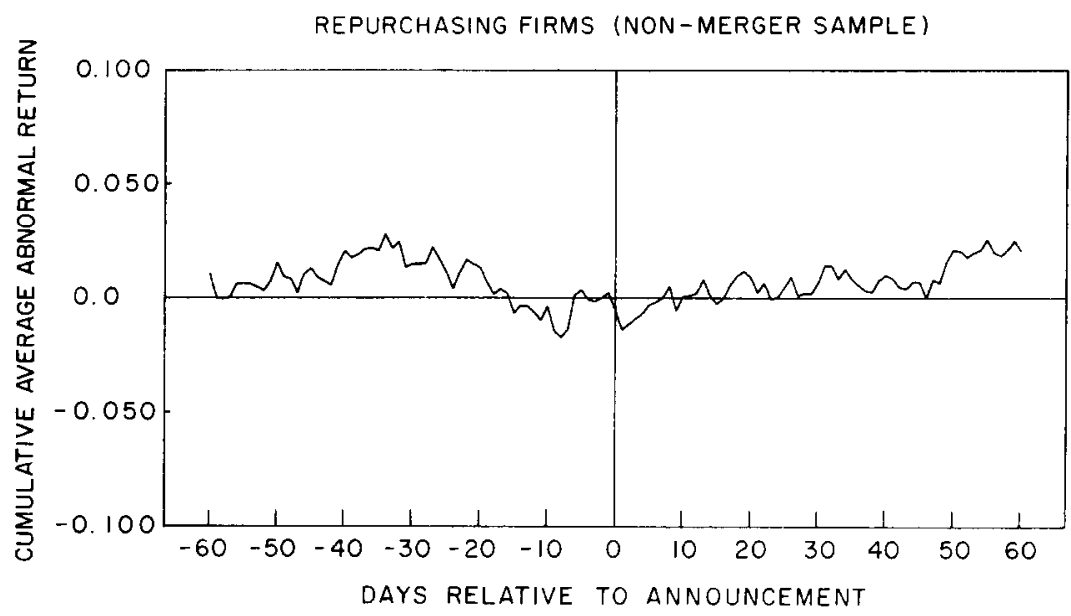

REPURCHASING FIRMS (MERGER SAMPLE)

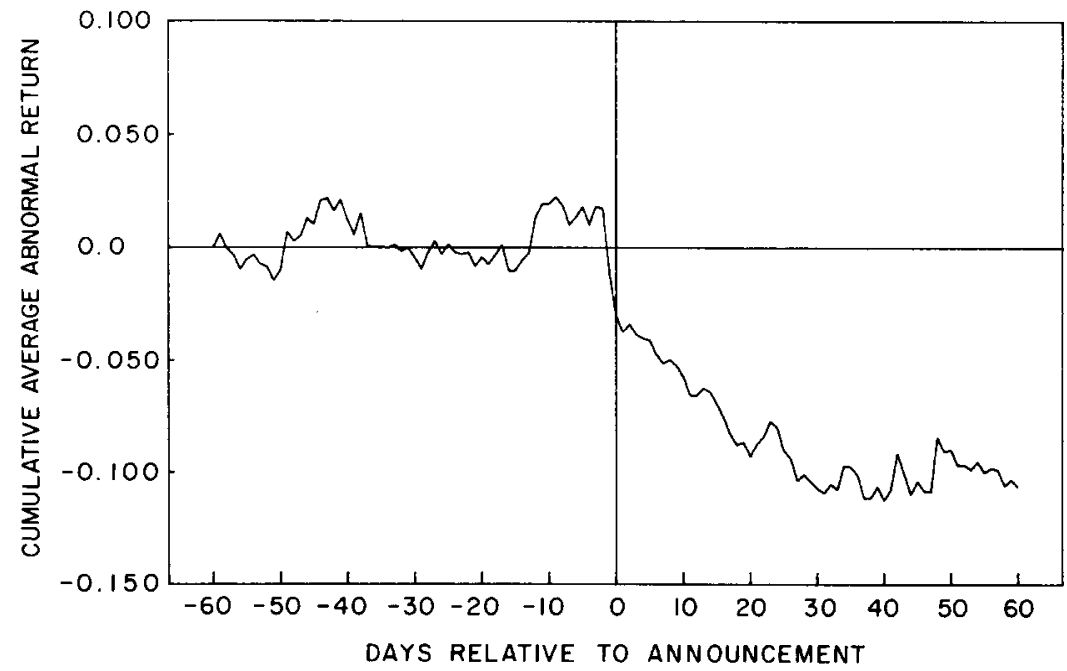

Fig. 2. Plots of cumulative average abnormal returns for companies repurchasing single blocks in the period 1974-1980: 40 'non-merger' and 21 'merger' companies.

The impact of a merger termination on the wealth of non-participating stockholders of repurchasing firms is reported in table 3 and fig. 2. For the sub-sample of 'non-merger' repurchasers, the $C A R_{-1,1}$ statistic is $-1.40 \%$ with a $t$-statistic of -1.97 , and the $C A R_{-1,18}$ statistic is $0.95 \%$ with a $t$-statistic of 0.63 . For these 40 repurchasing firms, 26 of the individual $C A R_{1.1}$ statistics and 20 of the $C A R_{-1.18}$ statistics are negative. Thus, the 
stockholders of these firms appear to experience a slight decrease in wealth. In contrast, the $C A R_{-1,1}$ statistic for the portfolio of 'merger' repurchasers is $-5.50 \%$ with a $t$-statistic of -7.14 , and the $C A R_{-1.18}$ statistic is $-10.50 \%$ with a $t$-statistic of -3.74 . For these 21 companies, 17 of the $C A R_{-1,1}$ statistics and 19 of the $C A R_{-1,18}$ statistics are negative. These results indicate that sharcholders of the repurchasing firms in the 'merger' sample sustain a significant wealth-loss as a result of the repurchase.

However, the termination of a take-over bid does not appear to have a negative impact on the value of the selling firm's shares, as table 4 and fig. 3 illustrate. The $C A R_{-1,1}$ statistic for the portfolio of 'non-merger' selling firms is $0.73 \%$ with a $t$-statistic of 0.94 , and the $C A R-1,18$ statistic is $4.26 \%$ with a $t$-statistic of 1.75 . For these 11 selling firms, 7 of the $C A R_{-1,1}$ statistics and 6 of the $C A R_{-1,18}$ statistics are positive. These results suggest that the subsample of 'non-merger' selling firms may gain slightly as a result of the transaction. For the portfolio of selling firms in the 'merger' sample, the $C A R_{-1,1}$ statistic is $1.82 \%$ with a $t$-statistic of 1.74 , while the $C A R_{-1,18}$ statistic is an insignificant $-0.40 \%$. For these 17 companies, 9 of the $C A R_{-1,1}$ statistics and 8 of the $C A R_{-1,18}$ statistics are positive. Thus, it appears that any negative effect of the merger termination on the value of the selling firm is more than offset by the premium paid by the repurchasing firm.

For the portfolio of 'non-merger' repurchasing firms, the $1.4 \%$ loss in value of the non-participating shares in the three days surrounding the block repurchase is inconsistent with the shareholders' interest hypothesis and provides some support - albeit weak since the relevant $t$-statistic is -1.97 - for the managers' interest hypothesis. The evidence from the portfolio of 'merger' repurchasing firms is less clear, since the substantial wealth-loss sustained by the non-participating stockholders may be caused by a 'merger termination' effect. In the next section, we concentrate on isolating the effect of a take-over termination by analyzing the returns, net of the repurchase premium, to participating and non-participating shareholders.

\subsection{Cross-sectional analysis}

The cross-sectional means of the fraction of the firm's shares repurchased, $F$, the premium paid by the non-participating stockholders, $\pi$, and the premium received by the seller, $\pi^{*}$, are presented in table 5 .

The statistics in table 5 show that while the means of the fraction of the firm repurchased, $\bar{F}$, are almost identical for the 'merger' and 'non-merger' sub-samples, the average repurchase premium paid, $\bar{\pi}$, is more than three times greater for the 'merger' sample than for the 'non-merger' sample (the difference is almost $14 \%$ with a $t$-statistic of 2.57 ). Furthermore, the mean premium received by the selling firms as a percentage of their pre-offer 
Table 4

Daily abnormal returns to the common stock of 11 companies selling single blocks to the issuing firm unaccompanied by a merger termination and 17 companies selling single blocks to the issuing firm accompanied by a merger termination in the period 1974-1980.

\begin{tabular}{|c|c|c|c|c|}
\hline \multirow[b]{2}{*}{$\begin{array}{l}\text { Days relative to } \\
\text { the announcement } \\
\text { date }\end{array}$} & \multicolumn{2}{|c|}{ No merger termination } & \multicolumn{2}{|c|}{ Merger termination } \\
\hline & $\begin{array}{l}\text { Daily } \\
\text { average } \\
\text { abnormal } \\
\text { return }\end{array}$ & $\begin{array}{l}\text { Cumulative } \\
\text { average } \\
\text { abnormal } \\
\text { return }\end{array}$ & $\begin{array}{l}\text { Daily } \\
\text { average } \\
\text { abnormal } \\
\text { return }\end{array}$ & $\begin{array}{l}\text { Cumulative } \\
\text { average } \\
\text { abnormal } \\
\text { return }\end{array}$ \\
\hline-60 & N.A. ${ }^{a}$ & 0.0123 & N.A. ${ }^{a}$ & 0.0045 \\
\hline-50 & & 0.0291 & & 0.0163 \\
\hline-40 & & 0.0345 & & 0.0034 \\
\hline-30 & & 0.0343 & & -0.0085 \\
\hline-20 & & 0.0391 & & -0.0141 \\
\hline-10 & & 0.0190 & & -0.0131 \\
\hline-9 & 0.0053 & 0.0243 & -0.0028 & -0.0159 \\
\hline-8 & -0.0015 & 0.0228 & -0.0043 & -0.0201 \\
\hline-7 & 0.0014 & 0.0241 & 0.0038 & -0.0163 \\
\hline-6 & 0.0085 & 0.0326 & 0.0050 & -0.0113 \\
\hline-5 & 0.0029 & 0.0355 & 0.0015 & -0.0098 \\
\hline-4 & -0.0031 & 0.0324 & 0.0046 & -0.0053 \\
\hline-3 & -0.0083 & 0.0241 & -0.0039 & -0.0091 \\
\hline-2 & 0.0002 & 0.0243 & 0.0048 & -0.0043 \\
\hline-1 & 0.0044 & 0.0287 & 0.0137 & 0.0093 \\
\hline 0 & 0.0035 & 0.0322 & 0.0023 & 0.0116 \\
\hline 1 & -0.0006 & 0.0316 & 0.0022 & 0.0139 \\
\hline 2 & 0.0067 & 0.0383 & 0.0054 & 0.0193 \\
\hline 3 & 0.0083 & 0.0466 & 0.0017 & 0.0209 \\
\hline 4 & 0.0006 & 0.0471 & 0.0002 & 0.0211 \\
\hline 5 & 0.0093 & 0.0564 & -0.0024 & 0.0188 \\
\hline 6 & -0.0072 & 0.0491 & 0.0029 & 0.0217 \\
\hline 7 & 0.0035 & 0.0527 & 0.0009 & 0.0226 \\
\hline 8 & -0.0027 & 0.0500 & 0.0064 & 0.0289 \\
\hline 9 & 0.0009 & 0.0509 & 0.0012 & 0.0301 \\
\hline 10 & 0.0084 & 0.0593 & 0.0009 & 0.0310 \\
\hline 20 & & 0.0572 & & -0.0112 \\
\hline 30 & & 0.0788 & & 0.0215 \\
\hline 40 & & 0.0776 & & 0.0337 \\
\hline 50 & & 0.0832 & & 0.0016 \\
\hline 60 & & 0.0948 & & 0.0082 \\
\hline Daily standard error & \multicolumn{2}{|c|}{0.0060} & \multicolumn{2}{|c|}{0.0050} \\
\hline 3-day standard crror & \multicolumn{2}{|c|}{0.0078} & \multicolumn{2}{|c|}{0.0082} \\
\hline 20-day standard error & \multicolumn{2}{|c|}{0.0244} & \multicolumn{2}{|c|}{0.0158} \\
\hline
\end{tabular}

${ }^{a}$ Not applicable. 

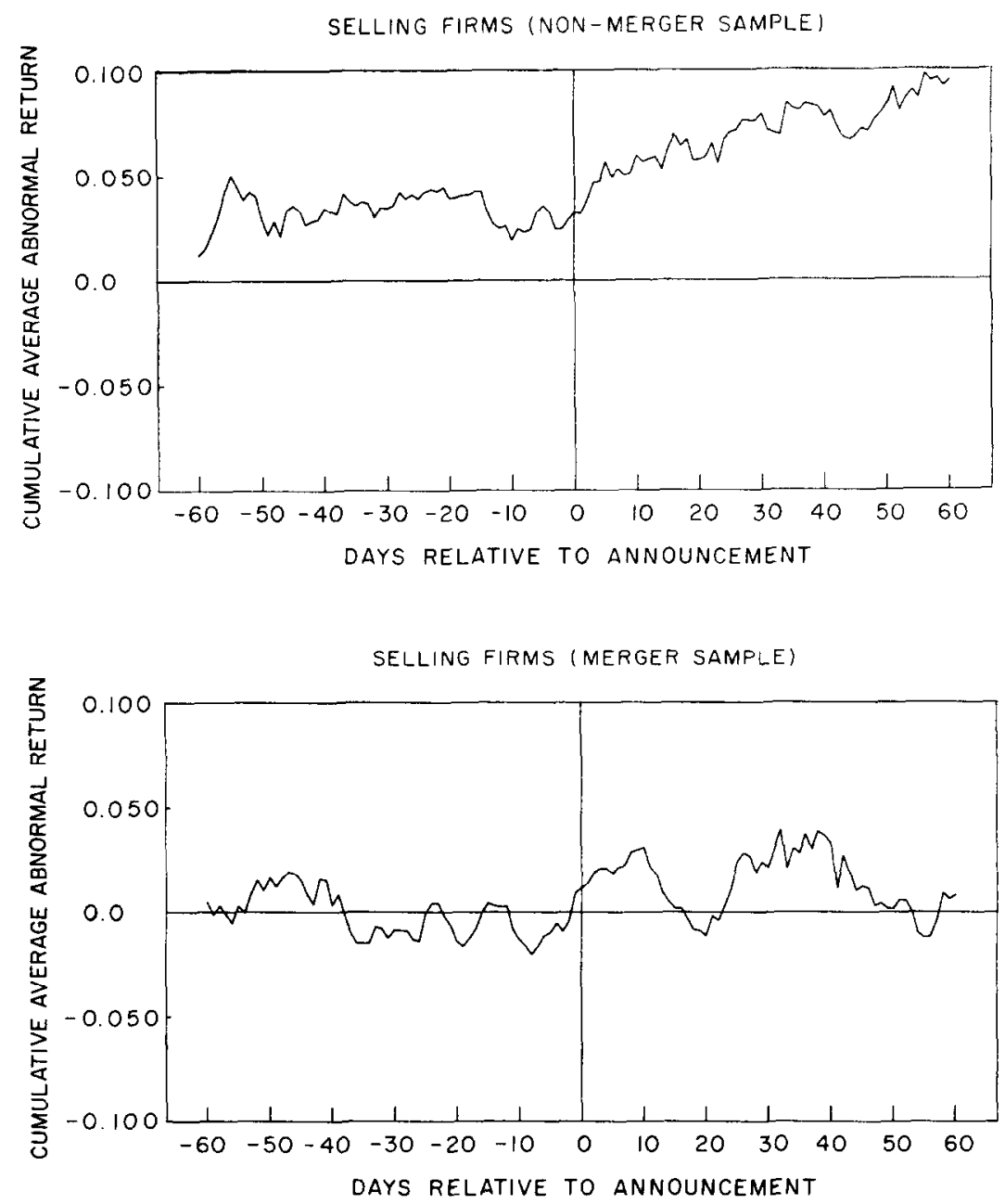

Fig. 3. Plots of cumulative average abnormal returns for companies selling single blocks to the issuing firm in the period 1974-1980: 11 'non-merger' and 17 'merger' companies.

values, $\bar{\pi}^{*}$, is also higher for the 'merger' sample (although the difference is not statistically significant). But if the termination of a take-over attempt is a value-decreasing event for target firms, why then are the shares of these 'merger' firms repurchased at higher premiums? To answer this question, we develop estimates of the wealth-effect of the block repurchase, net of the repurchase premium.

Following Bradley (1980) and Rosenfeld (1982), we note that if the repurchase offer contains information, the relcvant price for mcasuring any 


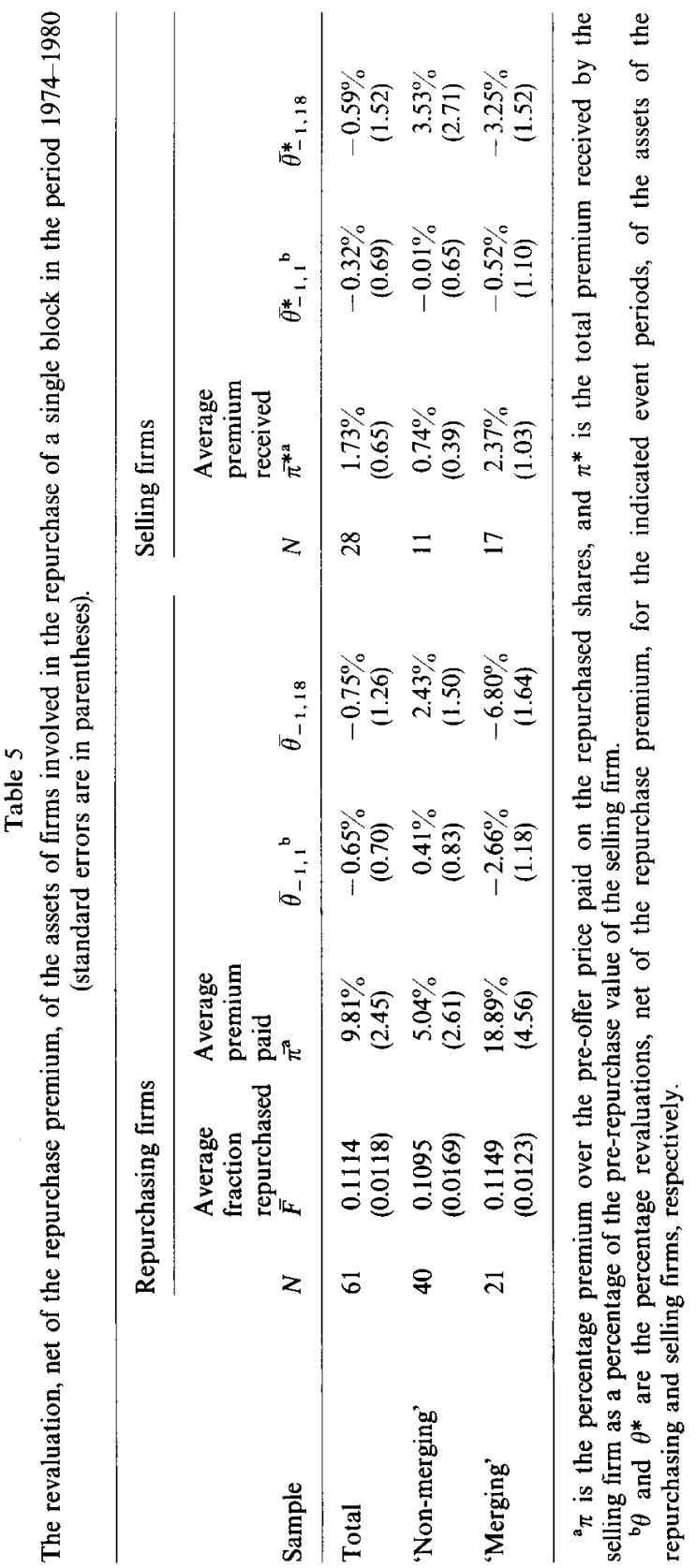


wealth transfer is the 'with information' share value, $P_{\mathrm{I}}$, rather than the preoffer share price, $P_{0}$. Thus the total premium received by the seller of a single block totalling $N_{\mathrm{B}}$ shares at a price $P_{\mathrm{B}}, N_{\mathrm{B}}\left(P_{\mathrm{B}}-P_{\mathrm{O}}\right)$, consists of a wealth transfer, $N_{\mathrm{B}}\left(P_{\mathrm{B}}-P_{\mathrm{I}}\right)$, and an information effect $N_{\mathrm{B}}\left(P_{\mathrm{I}}-P_{\mathrm{O}}\right)$. Similarly, the post-repurchase share price, $P_{\mathrm{E}}$, of the remaining shares, $\left(N_{\mathrm{O}}-N_{\mathrm{B}}\right)$, will reflect both the wealth transferred, $\left(N_{\mathrm{O}}-N_{\mathrm{B}}\right) \cdot\left(P_{\mathrm{E}}-P_{\mathrm{V}}\right)$, and the information effect, $\left(N_{\mathrm{O}}-N_{\mathrm{B}}\right) \cdot\left(P_{\mathrm{I}}-P_{\mathrm{O}}\right)$.

The informational impact of the repurchase on the total value of the repurchasing firm, $N_{\mathrm{O}}\left(P_{1}-P_{\mathrm{O}}\right)$, can be reformulated as

$$
\begin{aligned}
N_{\mathrm{O}}\left(P_{\mathrm{I}}-P_{\mathrm{O}}\right)= & N_{\mathrm{B}}\left(P_{\mathrm{I}}-P_{\mathrm{O}}\right)+\left(N_{\mathrm{O}}-N_{\mathrm{B}}\right) \cdot\left(P_{\mathrm{I}}-P_{\mathrm{O}}\right) \\
= & N_{\mathrm{B}}\left\{\left(P_{\mathrm{B}}-P_{\mathrm{O}}\right)-\left(P_{\mathrm{B}}-P_{\mathrm{I}}\right)\right\} \\
& +\left(N_{\mathrm{O}}-N_{\mathrm{B}}\right) \cdot\left\{\left(P_{\mathrm{E}}-P_{\mathrm{O}}\right)-\left(P_{\mathrm{E}}-P_{\mathrm{I}}\right)\right\} .
\end{aligned}
$$

Since, for an all-equity firm, the wealth received by the seller, $N_{\mathrm{B}}\left(P_{\mathrm{B}}-P_{\mathrm{l}}\right)$, equals the wealth transferred from the non-participating shareholders, $\left(N_{\mathrm{O}}-N_{\mathrm{B}}\right) \cdot\left(P_{\mathrm{E}}-P_{\mathrm{I}}\right)$, we can cancel these terms, leaving

$$
N_{\mathrm{O}}\left(P_{\mathrm{I}}-P_{\mathrm{O}}\right)=N_{\mathrm{B}}\left(P_{\mathrm{B}}-P_{\mathrm{O}}\right)+\left(N_{\mathrm{O}}-N_{\mathrm{B}}\right) \cdot\left(P_{\mathrm{E}}-P_{\mathrm{O}}\right) .
$$

Dividing through by $N_{\mathrm{O}} P_{\mathrm{O}}$, and noting that $F$ is the fraction of the firm's shares repurchased, we obtain

$$
\left(P_{\mathrm{I}}-P_{\mathrm{O}}\right) / P_{\mathrm{O}}=F\left\{\left(P_{\mathrm{B}}-P_{\mathrm{O}}\right) / P_{\mathrm{O}}\right\}+(1-F)\left\{\left(P_{\mathrm{E}}-P_{\mathrm{O}}\right) / P_{\mathrm{O}}\right\} .
$$

Then, defining $\theta_{-1, T}$ as the information-induced percentage change in the value of the assets of the repurchasing firm, and noting that $\pi$ is the percentage premium over the pre-offer price, we can write

$$
0_{-1, T}=F \cdot \pi+(1-F) R_{-1, T},
$$

where $R_{-1, T}$ is the realized percentage return to the shares of the repurchasing firm from one day before the announcement through day $T$. Empirically, we use the abnormal performance index, $A P I_{-1, T}$, to estimate this return, where

$$
A P I_{-1, T}=\prod_{\tau=-1}^{T}\left(1+A R_{\tau}\right)-1 .
$$

If the repurchase premium is the only effect involved, and therefore $P_{\mathrm{I}}$ equals $P_{\mathrm{O}}$, then the price of the remaining non-participating shares will adjust to reflect just the wealth transfer involved. This value decrease, 
$(1-F) A P I_{-1, T}$, will offset the total premium received by the seller, $F \cdot \pi$, and $\theta$ will be zero. If a block repurchase also conveys positive information concerning the repurchasing firm, and therefore $P_{1}$ exceeds $P_{0}$, then the decrease in value of the remaining shares will be less than the total premium received by the seller of the block and $\theta$ will be positive. In contrast, if a merger termination is implied by the repurchase announcement, with negative implications for the shares of the repurchasing company, then $\theta$ will be negative.

Since the total wealth transferred to the selling firm equals $N_{\mathrm{B}}\left(P_{\mathrm{B}}-P_{\mathrm{O}}\right)$, the informational impact on the value of the selling firm is given by

$$
N_{\mathrm{O}}^{*}\left(P_{\mathrm{I}}^{*}-P_{\mathrm{O}}^{*}\right)=N_{\mathrm{O}}^{*}\left(P_{\mathrm{E}}^{*}-P_{\mathrm{O}}^{*}\right)-N_{\mathrm{B}}\left(P_{\mathrm{B}}-P_{\mathrm{O}}\right),
$$

where all of the variables are defined above and the ${ }^{*}$ superscript refers to the selling firm. Dividing through by $N_{\mathrm{O}}^{*} P_{\mathrm{O}}^{*}$ and taking percentages,

$$
\theta_{-1, T}^{*}=R_{-1, T}^{*}-\pi^{*} .
$$

If the block repurchase signals positive information about the selling firm, then $\theta_{-1, T}^{*}$ will be positive; if the repurchase conveys bad news about the selling firm, then $\theta_{-1, T}^{*}$ will be negative.

The average information effect, as measured by the $\bar{\theta}_{-1,1}$ and $\bar{\theta}_{-1,18}$ estimates reported in table 5, for the sample of 'non-merger' repurchasing firms is positive, albeit insignificantly different from zero. This implies that, for these non-participating shareholders, the negative impact of the wealth transfer is the dominant effect involved in single block repurchases.

For the repurchasing firms in the 'merger' sample, the results are quite different. The information effect is definitely negative since $\bar{\theta}_{-1,1}$ is $-2.7 \%$ with a $t$-statistic of -2.3 , and $\bar{\theta}_{-1,18}$ is $-6.8 \%$ with a $t$-statistic of -4.1 . This suggests that a block repurchase that signals the termination of a pending merger bid significantly reduces the value of the repurchasing firm beyond the wealth-transfer associated with the repurchase premium.

The average information effect, as measured by the $\bar{\theta}_{-1,1}^{*}$ and $\bar{\theta}_{-1,18}^{*}$ estimates reported in table 5, for the sample of 'non-merger' selling firms is also insignificantly different from zero. For these repurchases, the gain to participating stockholders can be fully 'explained' by the repurchase premium. But the returns to the selling firms in the 'merger' sample indicate a small negative information effect: the $\theta_{-1,1}^{*}$ statistic is insignificant, but $\theta_{-1,18}^{*}$ is $-3.25 \%$ with a $t$-statistic of -2.14 . By this estimate, the market appears to have anticipated a value-increasing acquisition by the prospective acquiring firm, and responds to the termination of the take-over attempt by slightly devaluing the selling firm's shares.

Given these results, the question arises: Why do the managers of the acquiring firm abandon the take-over attempt? One possible explanation is 
that they become disenchanted with the prospects of the repurchasing firm as a take-over candidate. But in this case why does the target firm pay a significantly higher premium for the repurchased block? A large block holding gives the acquiring firm the power to disrupt the activities of the repurchasing firm. The repurchase at the time of the merger termination precludes further interference by the selling firm and may therefore justify the payment of a relatively high premium. However, this hypothesis is inconsistent with the evidence of Dann and DeAngelo (1983) who find that the $C A R_{-1,1}$ for their sample of 19 standstill agreements unaccompanied by a negotiated stock repurchase is $-3.72 \%$, while the $C A R_{-1,1}$ for their total sample of 30 standstill agreements (including those accompanied by a negotiated stock repurchase) is $-4.39 \%$, i.e., assuming that the standstill agreement is tantamount to a merger termination, an accompanying repurchase does not appear to generate wealth for the non-participating stockholders.

An alternative explanation is that, although the proposed acquisition is a positive net present value project, the managers of the acquiring firm are induced to abandon their take-over plans and sell their holding because of the significant premium offered by the managers of the repurchasing firm. By repurchasing this block, these managers secure greater control of the repurchasing firm at the expense of their remaining stockholders. This hypothesis is consistent with the evidence presented above.

To summarize, we consider that the data presented in table 5 are inconsistent with the hypothesis that the managers of repurchasing firms are acting in their stockholder's interest - particularly when the repurchase signals the termination of a take-over attempt. In such a case, the data suggest that the intent of the managers of repurchasing firms in repurchasing the block is to thwart a profitable take-over, presumably to enhance their own welfare.

As a final test of the effects of a merger termination, we combine the 'merger' and 'non-merger' samples and regress the change in wealth of the stockholders on the total premium paid, $N_{\mathrm{B}}\left(P_{\mathrm{B}}-P_{\mathrm{O}}\right)$, and a 'merger' dummy variable, with a value of 1 if the observation is in the 'merger' sample and 0 otherwise. The dependent variable in the repurchasing regression is the change in wealth of the non-participating shareholders, $\Delta W$, and the dependent variable in the selling regression is the change in wealth of the stockholders of the selling company, $\Delta W^{*}$. Empirically, $\Delta W$ is the preannouncement value of the non-participating shares, $\left(N_{\mathrm{O}}-N_{\mathrm{B}}\right) P_{\mathrm{O}}$, multiplied by $A P I_{-1,18}$ and $\Delta W^{*}$ is $N_{0}^{*} \cdot P_{0}^{*} \cdot A P I_{-1,18}^{*}$. Thus, we run the following cross-sectional regressions:

$$
\begin{aligned}
\Delta W= & \gamma_{0}+\gamma_{1}(\text { repurchase premium })+\gamma_{2}\left({ }^{\text {'merger' }}\right) \\
& +\gamma_{3}(\text { fraction repurchased })+\gamma_{4}\left({ }^{(} \text {'standstill' }\right)+\varepsilon,
\end{aligned}
$$




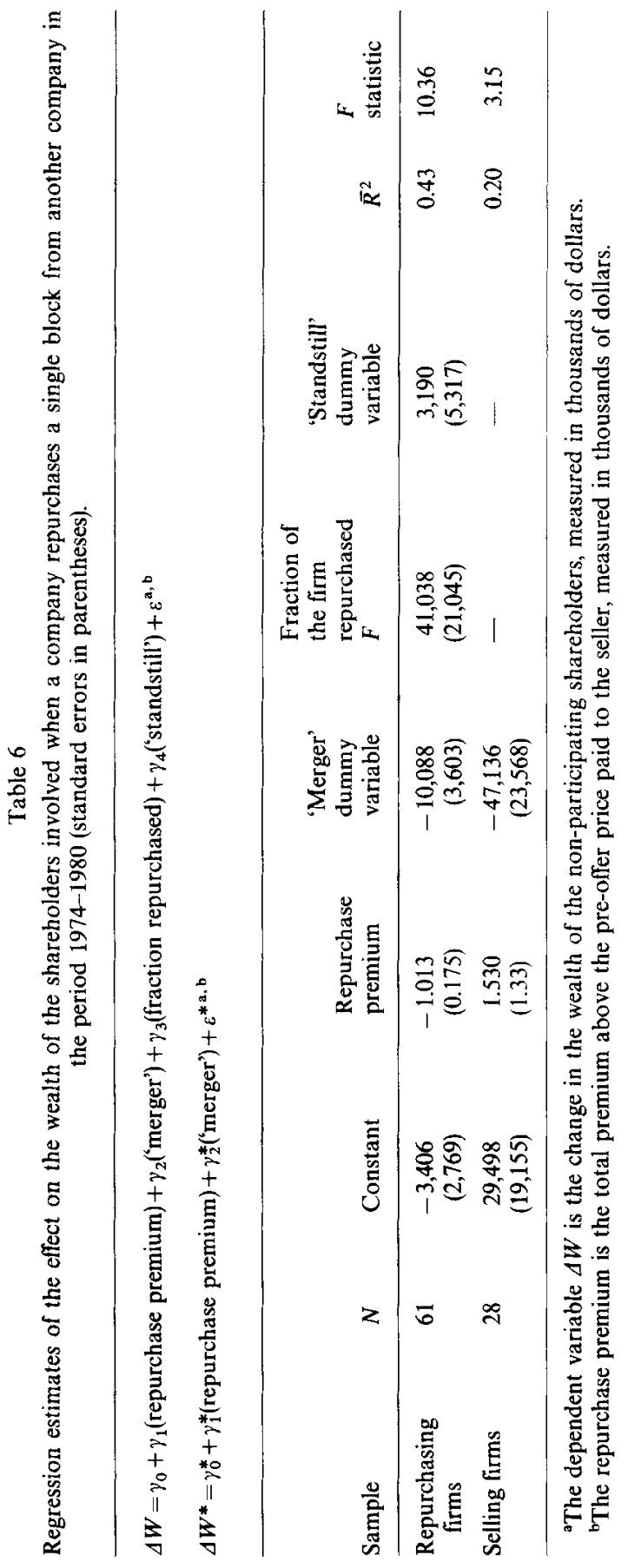




$$
\Delta W^{*}=\gamma_{0}^{*}+\gamma_{1}^{*}(\text { repurchase premium })+\gamma_{2}^{*}\left(\text { (merger' }^{\prime}\right)+\varepsilon^{*} .
$$

If these regressions are correctly specified, we expect $\gamma_{1}=-1$ and $\gamma_{1}^{*}=1$. In addition, the estimates of $\gamma_{2}$ and $\gamma_{2}^{*}$ will give an indication of the effect of a merger termination on the value of the repurchasing and selling firms, respectively.

The results of the cross-section regressions specified above are reported in table 6 . The repurchase premium coefficients for the repurchasing and selling firms, $\hat{\gamma}_{1}$ and $\hat{\gamma}_{1}^{*}$, are insignificantly different from their theoretical values of -1 and 1 , respectively. The estimated constants of the regressions indicate that, on average, the repurchasing shareholders lose an additional $\$ 3.4$ million and the selling shareholders gain an additional \$29.5 million (although the $t$-statistics in both cases are insignificant). But more importantly, the significantly negative 'merging' dummy variables indicate that repurchases that mark the termination of a take-over attempt reduce the values of both firms, abstracting from the repurchase premium. This loss averages $\$ 10.1$ million for repurchasing shareholders and $\$ 47.1$ million for selling shareholders.

An additional variable in the repurchasing equation, the fraction repurchased, is marginally significant. We interpret its positive coefficient to imply that the remaining shareholders are better off if the given level of premium is paid for a larger rather than a smaller block. We also included a leverage measure in eq. (5) since bondholders may have a portion of the wealth transferred to the seller, reducing the loss of the remaining shareholders. However, we found the coefficient on this variable to be insignificantly different from zero.

Since standstill agreements are often associated with merger terminations, they may be synonymous with the announcement of the termination of a take-over bid. To test this hypothesis, we include a standstill dummy variable, with a value of 1 if a standstill agreement is signed, in the 'repurchasing firms' regression. The coefficient reported in table 6 is insignificantly different from zero. For our sample of single block repurchases, this suggests that the news of the merger termination and the announcement of a standstill agreement have the same informational content.

\section{4. 'Insider' repurchases}

In his study of secondary distributions of large blocks, Scholes (1972) finds that when corporations and corporate officers sell a block of shares, the average abnormal return to the remaining shares on the day of the sale is $-1.1 \%$ and the cumulative average abnormal return from the day of the sale to 10 days after the secondary distribution is $-2.1 \%$. He interprets this wcalth loss as a reaction by the market to the disclosure of the identity of 
the sellers - 'insiders' who are presumed to possess adverse information. The purpose of this section is to complement Scholes's results by analyzing the sales of blocks by corporate officers to their own companies.

Table 7

Daily abnormal returns to the common stock of 25 companies repurchasing single blocks from insiders in the period 1975-1980.

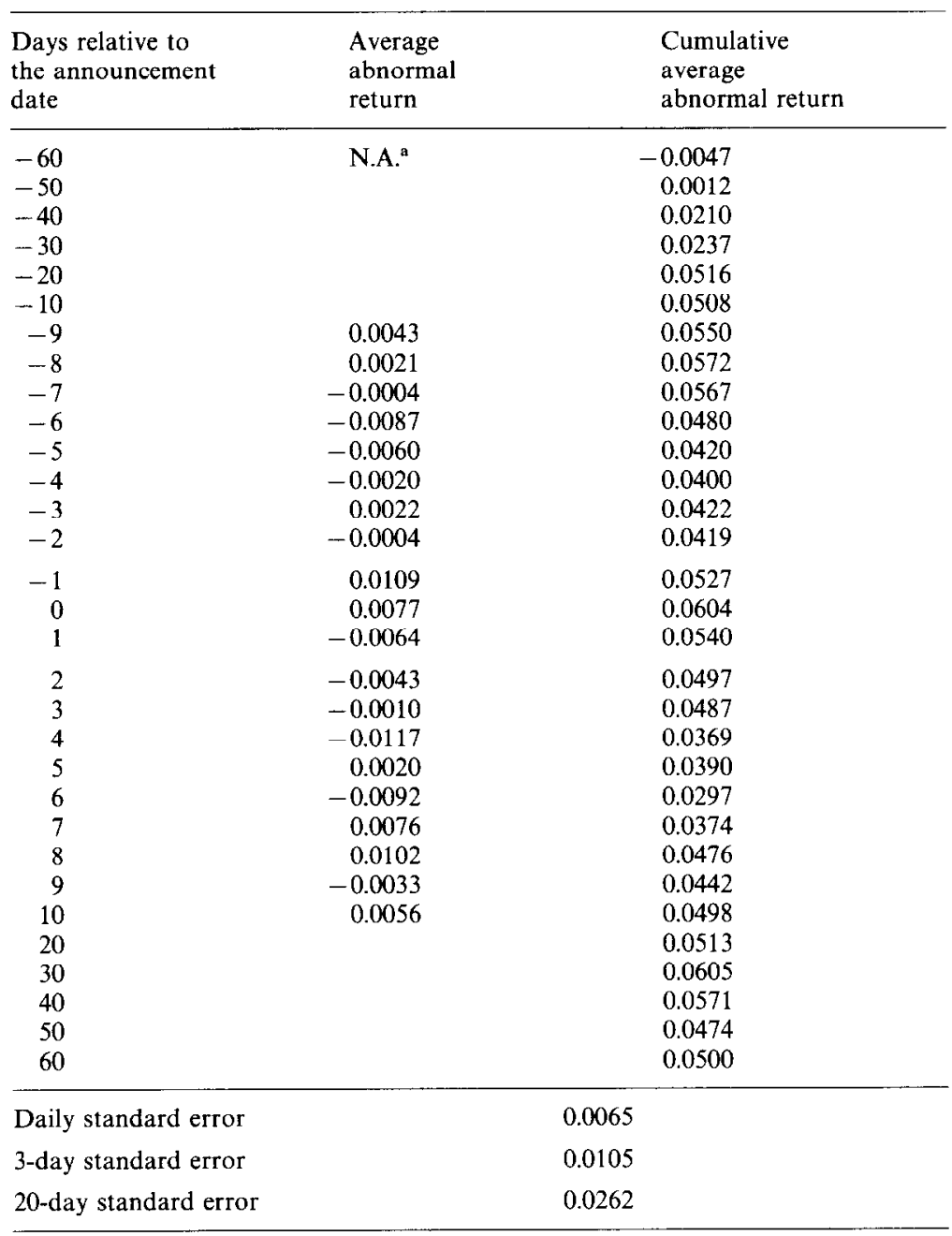

${ }^{a}$ Not applicable.

The summary statistics for our sample of 15 repurchases from corporate officers and 10 repurchases from the estates of deceased corporate officers and from foundations created by such insiders arc presented in table 1. The 
times series methodology discussed in section 3 is used to examine these repurchases. We analyzed the sub-groups separately, but the results were identical for the two groups. Therefore, we combined the data into one 'insiders' sample and report results for this entire group.

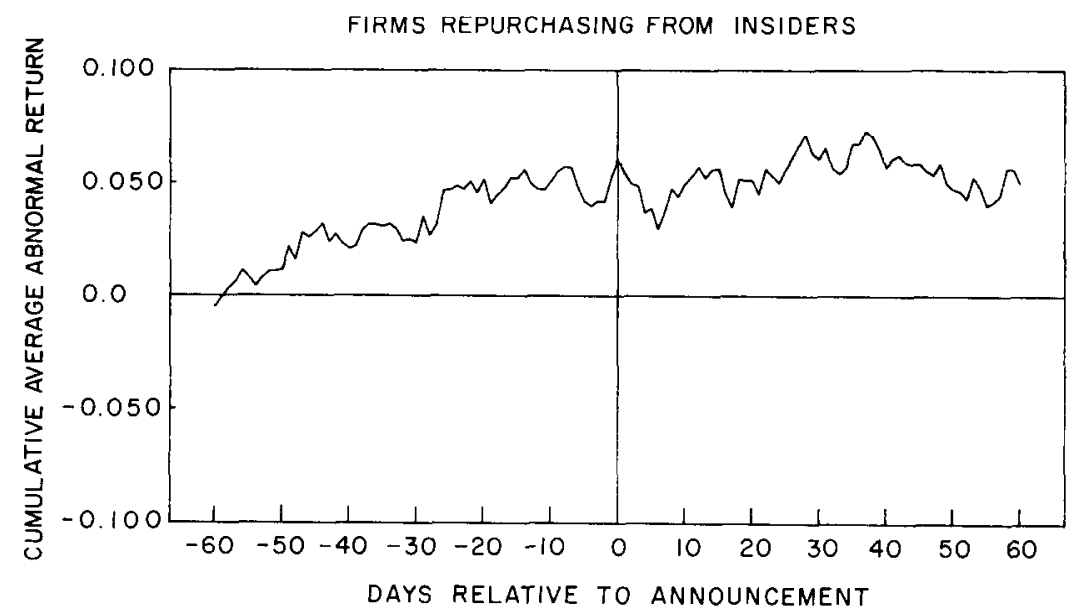

Fig. 4. Plot of cumulative average abnormal returns for 25 companies repurchasing single blocks from insiders in the period 1975-1980.

The market reaction to the announcement of block repurchases from insiders is shown in table 7 and fig. 4 . This reaction is significantly different from that presented in section 3 for single block repurchases. Rather than being negative, as implied by the repurchase premium, the $C A R_{-1,1}$ statistic is $1.21 \%$ with a $t$-statistic of 1.15 , and the $C A R_{-1.18}$ statistic is $1.00 \%$ with a $t$-statistic of 0.38 . Furthermore, the cross-sectional analysis of the change in asset values, net of the repurchase premium, confirms the existence of an offsetting positive effect: our estimate of the information effect, $\bar{\theta}_{-1,1}$, is $1.72 \%$ with a $t$-statistic of 1.61 .

This slight wealth gain is especially interesting when contrasted to the wealth loss reported by Scholes. If the market cannot costlessly differentiate between sales by insiders possessing adverse economic information and sales by insiders for purely portfolio reasons, then the price of the remaining shares may decrease in the short-run even when the insider sale is part of a portfolio rebalancing strategy. In such an instance, repurchase of the insider block by the company may solve the asymmetric information problem involved by signaling the absence of adverse economic information to the market. In response to this signal, the price of the remaining shares will not fall, and may indeed rise. In contrast, a decision by the company not to repurchase a block from an insider before it is offered to the market through 
a secondary distribution may confirm that adverse economic information is involved.

\section{Repurchases of small shareholdings}

Companies consistently justify their offer to repurchase small shareholdings as an effort to reduce the costs of mailing dividend checks, annual and quarterly reports, proxy statements or other literature to shareholders. In order to test this hypothesis, we use the standard cumulative abnormal return analysis described in section 3 .

Table 8

Daily abnormal returns to the common stock of 15 companics repurchasing small shareholdings in the period 1975-1979.

\begin{tabular}{|c|c|c|}
\hline $\begin{array}{l}\text { Days relative to } \\
\text { the announcement } \\
\text { date }\end{array}$ & $\begin{array}{l}\text { Average } \\
\text { abnormal returna }\end{array}$ & $\begin{array}{l}\text { Cumulative } \\
\text { average } \\
\text { abnormal return }\end{array}$ \\
\hline $\begin{array}{l}-60 \\
-50 \\
-40 \\
-30 \\
-20 \\
-10 \\
-9 \\
-8 \\
-7 \\
-6 \\
-5 \\
-4 \\
-3 \\
-2\end{array}$ & $\begin{array}{r}\text { N.A. } \\
\\
\\
\\
0.0188 \\
-0.0095 \\
0.0061 \\
0.0008 \\
0.0114 \\
-0.0049 \\
-0.0101 \\
0.0104\end{array}$ & $\begin{array}{r}-0.0092 \\
-0.0235 \\
-0.0079 \\
-0.0077 \\
-0.0179 \\
-0.0114 \\
0.0074 \\
-0.0021 \\
0.0040 \\
0.0049 \\
0.0163 \\
0.0114 \\
0.0013 \\
0.0117\end{array}$ \\
\hline $\begin{array}{r}-1 \\
0 \\
1\end{array}$ & $\begin{array}{r}0.0125 \\
-0.0020 \\
-0.0014\end{array}$ & $\begin{array}{l}0.0242 \\
0.0223 \\
0.0208\end{array}$ \\
\hline $\begin{array}{r}2 \\
3 \\
4 \\
5 \\
6 \\
7 \\
8 \\
9 \\
10 \\
20 \\
30 \\
40 \\
50 \\
60\end{array}$ & $\begin{array}{r}-0.0031 \\
0.0016 \\
0.0001 \\
-0.0044 \\
-0.0001 \\
-0.0056 \\
-0.0071 \\
0.0165 \\
0.0050\end{array}$ & $\begin{array}{l}0.0177 \\
0.0194 \\
0.0195 \\
0.0151 \\
0.0150 \\
0.0094 \\
0.0023 \\
0.0188 \\
0.0239 \\
0.0405 \\
0.0274 \\
0.0452 \\
0.0523 \\
0.0515\end{array}$ \\
\hline
\end{tabular}

${ }^{a}$ The daily standard error of the portfolio abnormal return in the estimation period is 0.0070 .

${ }^{\mathrm{b}}$ Not applicable. 
The average abnormal return for day $t$ and the cumulative average abnormal return to day $t$ from 60 days before the announcement for the portfolio of companies repurchasing small shareholdings are presented in table 8 . The time-series of the cumulative abnormal return for this portfolio is plotted in fig. 5 .

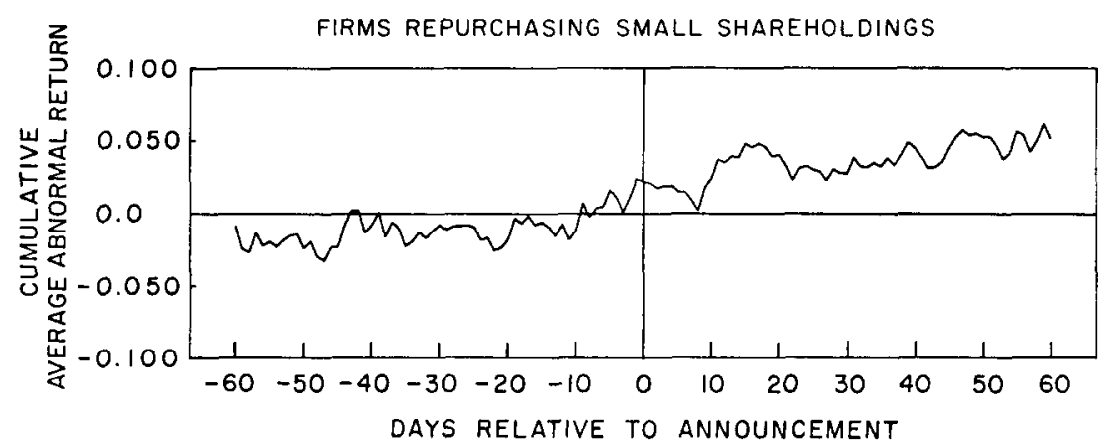

Fig. 5. Plot of cumulative average abnormal returns for 15 firms repurchasing small shareholdings in the period 1975-1979.

There is a positive average abnormal return of $1.25 \%$ on the day before the announcement and the abnormal return for the three days surrounding the announcement is $0.92 \%$ with $t$-statistics of 1.78 and 0.90 , respectively. This evidence weakly favors the hypothesis that companies, in repurchasing small shareholdings, decrease shareholder servicing costs. This suggests that one of the reasons given for large block repurchases - to reduce servicing costs - is consistent with the shareholders' interest hypothesis. However, several colleagues have pointed out that the one-day return of $1.25 \%$ is quite large compared with a priori estimates of the decrease in servicing costs. The result is therefore also consistent with the hypothesis that managers are using the small shareholding repurchase to signal positive information to the market.

\section{Conclusions}

Several authors have studied the wealth effects of the various forms of share repurchases. The results of these studies are reported in table 9. Analyzing intrafirm tender offers, Masulis (1980b), Dann (1981), Vermaelen (1981) and Rosenfeld (1982) all find that the average value of the remaining shares, rather than falling by $4 \%$ to reflect the premium paid to the tendering shareholders, actually rises by $15 \%$ as a result of the repurchase. Although they disagree as to the cause of this off-setting positive wealth effect, they all conclude that their results are consistent with the shareholders' interest 


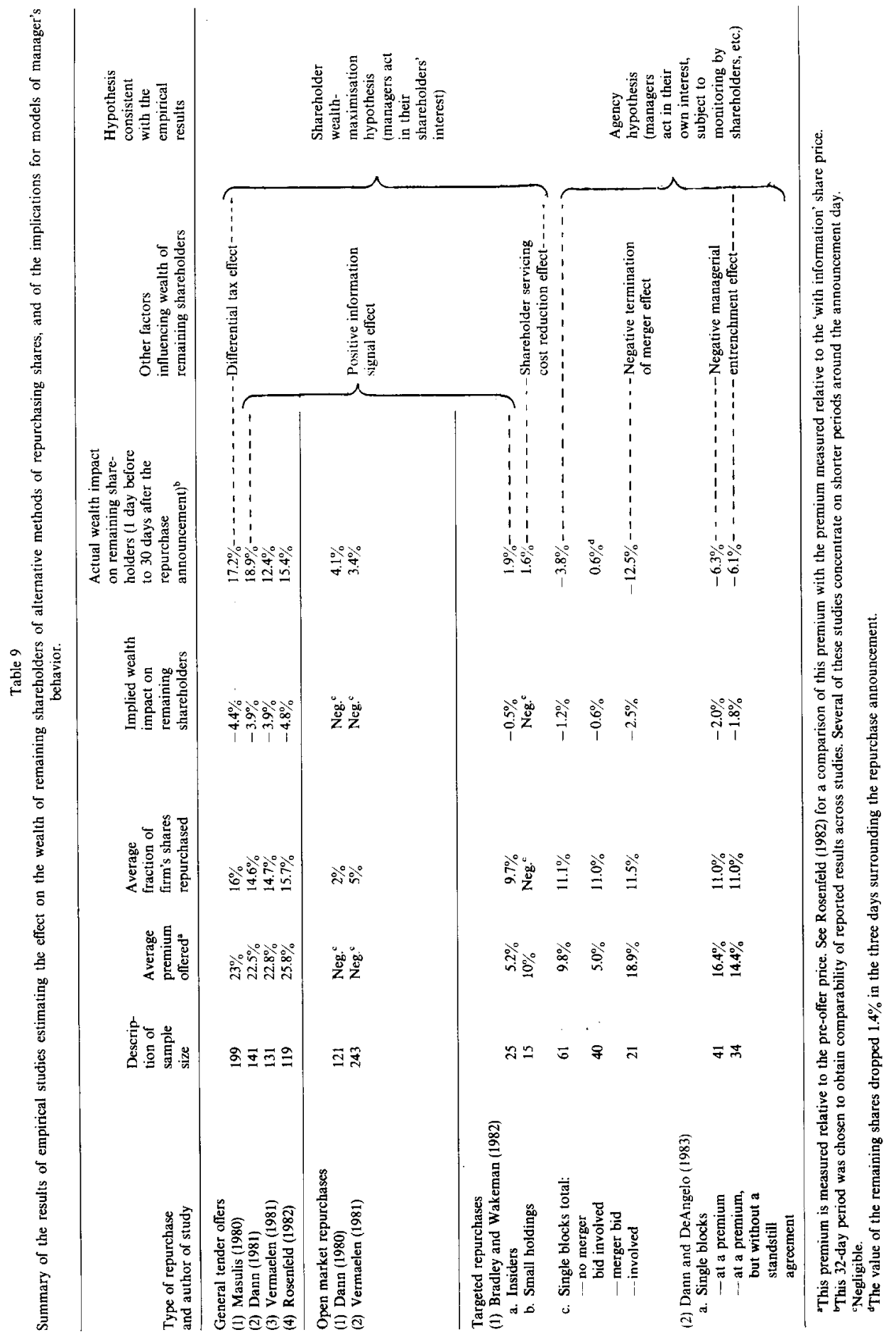


hypothesis. Vermaelen's (1981) results for open market repurchases and our results for targeted repurchases from insiders and small shareholders are consistent with this conclusion.

The data presented in this paper and in Dann and DeAngelo (1983) indicate that the repurchase of a single block implies an average wealth loss of $1-2 \%$ for the remaining stockholders of the repurchasing firm. But our evidence reveals no off-setting positive effects. Indeed, the wealth loss of the non-participating shareholders of these firms is significantly greater: Dann and DeAngelo document a $6 \%$ loss and we find a $4 \%$ loss in value. Moreover, our results show that this wealth-loss is much greater $(13 \%)$ for repurchases that mark the termination of a take-over bid. While a greater wealth-loss is to be expected in the wake of the termination of a take-over bid, the fact that these repurchases are effected at significantly higher premiums appears to be inconsistent with the shareholders' interest hypothesis.

The evidence presented in this paper is consistent with the hypothesis that a single block repurchase from another corporation is used by the managers of the repurchasing firm to eliminate a threat to their control over the firm. In a sense, they use the repurchase premium to bribe the selling stockholder into giving up his interest in the firm and, by implication, cease monitoring the firm's activities. As a result, the managers of the repurchasing firm are able to pursue an operating strategy that is more in line with their own interests and less in line with those of their stockholders.

It must be stressed that we do not view this evidence as a blanket indictment against the shareholders' interest hypothesis. Indeed, a block repurchase from another corporation is a relatively rare event. Nevertheless, based on our analysis, we conclude that these transactions do not generally enhance the welfare of the stockholders of the repurchasing firm. This raises an interesting question as to why boards of directors and shareholders vote their approval for such repurchases. We found that, for our sample, six lawsuits had been filed by shareholders attempting to thwart single block repurchases. In one case, the company responded by converting the repurchase into a general tender offer. In the other five cases, however, the managers of the repurchasing firm argued that the premium was justified in order to remove from the company 'outside influences inimical to the shareholders' best interests'. The courts were sympathetic to this argument and consistently ruled in favor of the managers. The evidence presented in this paper casts serious doubt on the wisdom of these judicial rulings.

\section{References}

Alchian, A.A. and H. Demsetz, 1972, Production, information costs, and economic organization, American Fconomic Review 62,777-795. 
Bradley, M., 1980, Interfirm tender offers and the market for corporate control, Journal of Business 53, 345-376.

Dann, L.Y., 1980, The effect of common stock repurchase on stockholder returns, Unpublished dissertation (University of California, Los Angeles, CA).

Dann, L.Y., 1981, Common stock repurchases: An analysis of returns to bondholders and stockholders, Journal of Financial Economics 9, 113-138.

Dann, L.Y. and H. DeAngelo, 1983, Standstill agreements, privately negotiated stock repurchases, and the market for corporate control, Journal of Financial Economics 11, this issue.

Dimson, E., 1979, Risk measurement when shares are subject to infrequent trading, Journal of Financial Economics 7, 197-226.

Dodd, P., 1980, Merger proposals, management discretion, and stockholder wealth, Journal of Financial Economics 8, 105-138.

Dodd, P. and R. Ruback, 1977, Tender offers and stockholder returns: An empirical analysis, Journal of Financial Economics 5, 351-373.

Fama, E.F., 1976, Foundations of finance (Basic Books, New York).

Jensen, M.C. and W.H. Meckling, 1976, Theory of the firm: Management behavior, agency costs and ownership structure, Journal of Financial Economics 3, 305-360.

Langetieg, T., 1978, An application of a three-factor performance index to measure stockholders gains from merger, Journal of Financial Economics 6, 365-384.

Malatesta, P., 1981, Corporate mergers, Unpublished dissertation (University of Rochester, Rochester, NY).

Mandelker, G., 1974, Risk and return: The case of merging firms, Journal of Financial Economics 1, 303-335.

Manne, H.G., 1965, Mergers and the market for corporate control, Journal of Political Economy 73, 110-120.

Masulis, R.W., 1980a, The effects of capital structure change on security prices: A study of exchange offers, Journal of Financial Economics 8, 139-178.

Masulis, R.W., 1980b, Stock repurchase by tender offer: An analysis of the causes of common stock price changes, Journal of Finance 35, 305-319.

Rosenfeld, A., 1982, Repurchase offers: Information adjusted premiums and shareholders' response, Working paper (Krannert Graduate School of Management, Purdue University, West Lafayette, IN).

Scholes, M.S., 1972, The market for securities: Substitution versus price pressure and the effects of information on share prices, Journal of Business 45, 179-211.

Vermaelen, T., 1981, Common stock repurchases and market signalling: An empirical study, Journal of Financial Economics, 9, 139-183. 